\title{
Althusser's Maoism-Machiavellianism and the Maoist "People"/“Masses”as a China Question of Western Theory
}

\author{
Fang Yan \\ Central China Normal University
}

Follow this and additional works at: https://docs.lib.purdue.edu/clcweb

(3)

Part of the Comparative Literature Commons

Dedicated to the dissemination of scholarly and professional information, Purdue University Press selects, develops, and distributes quality resources in several key subject areas for which its parent university is famous, including business, technology, health, veterinary medicine, and other selected disciplines in the humanities and sciences.

CLCWeb: Comparative Literature and Culture, the peer-reviewed, full-text, and open-access learned journal in the humanities and social sciences, publishes new scholarship following tenets of the discipline of comparative literature and the field of cultural studies designated as "comparative cultural studies." Publications in the journal are indexed in the Annual Bibliography of English Language and Literature (Chadwyck-Healey), the Arts and Humanities Citation Index (Thomson Reuters ISI), the Humanities Index (Wilson), Humanities International Complete (EBSCO), the International Bibliography of the Modern Language Association of America, and Scopus (Elsevier). The journal is affiliated with the Purdue University Press monograph series of Books in Comparative Cultural Studies. Contact: <clcweb@purdue.edu>

\section{Recommended Citation}

Yan, Fang. "Althusser's Maoism-Machiavellianism and the Maoist "People"/"Masses"as a China Question of Western Theory." CLCWeb: Comparative Literature and Culture 22.5 (2020): <https://doi.org/10.7771/1481-4374.3831>

This text has been double-blind peer reviewed by $2+1$ experts in the field.

The above text, published by Purdue University Press @P Purdue University, has been downloaded 0 times as of 12/13/ 20.

This document has been made available through Purdue e-Pubs, a service of the Purdue University Libraries. Please contact epubs@purdue.edu for additional information.

This is an Open Access journal. This means that it uses a funding model that does not charge readers or their institutions for access. Readers may freely read, download, copy, distribute, print, search, or link to the full texts of articles. This journal is covered under the CC BY-NC-ND license. 


\section{PURDUE}

U N I V E R S I T Y UNIVERSITY PRESS < http://wWW.thepress.purdue.edu>

\section{CLCWeb: Comparative Literature and Culture}

ISSN 1481-4374 <http://docs.lib.purdue.edu/clcweb> Purdue University Press @Purdue University

CLCWeb: Comparative Literature and Culture, the peer-reviewed, full-text, and open-access learned journal in the humanities and social sciences, publishes new scholarship following tenets of the discipline of comparative literature and the field of cultural studies designated as "comparative cultural studies." In addition to the publication of articles, the journal publishes review articles of scholarly books and publishes research material in its Library Series. Publications in the journal are indexed in the Annual Bibliography of English Language and Literature (Chadwyck-Healey), the Arts and Humanities Citation Index (Thomson Reuters ISI), the Humanities Index (Wilson), Humanities International Complete (EBSCO), the International Bibliography of the Modern Language Association of America, and Scopus (Elsevier). The journal is affiliated with the Purdue University Press monograph series of Books in Comparative Cultural Studies. Contact: <clcweb@purdue.edu>

Volume 22 Issue 5 (December 2020) Article 3 Fang Yan,

"Althusser's Maoism-Machiavellianism and the Maoist 'People'/'Masses' as a China Question of Western Theory"

<http://docs.lib.purdue.edu/clcweb/vol22/iss5/3>

Contents of CLCWeb: Comparative Literature and Culture 22.5 (2020)

Special Issue The China Question in Western Theory. Ed. Liu Kang

< http://docs.lib.purdue.edu/clcweb/vol22/iss5/>

Abstract: Mao's concept of "people"/"masses" has entered Western theoretical production as the "China Question of Western Theory." This article argues that it is necessary to rethink Althusser's conception of "people"/"masses" from a Maoist-Machiavellian perspective. The factual overlapping of Althusser's Maoist heyday and his increased interest in Machiavelli makes it necessary to conduct a Maoism-Machiavellianism cross-reading of Althusser's theoretical works, although Althusser's Maoism exceeds his Machiavellianism on some occasions. Such an overlapping resulted in Althusser's reconfiguration of a notion of "people"/"masses" that is conjunctural, non-deterministic and nonhumanist, which led to his theses of the New Prince/Principality, the supremacy of class struggle, masses-make-history, and eventually, helped him to conceive a non-linear, non-historicist vision of social formations, namely, the theory of the encounter. 


\section{Fang YAN}

\section{Althusser's Maoism-Machiavellianism and the Maoist "People"/"Masses" as a China Question of Western Theory}

The current global populist and anarchist wave has brought the conception of the "people"/"masses" back into intellectual debates. However, among the Western Left, in the midst of dazzling postAlthusserian and post-Marxist debates, such as Antonio Negri \& Michael Hardt's "multitude," or Ernesto Laclau and Jacque Rancière's different invocations of the "people," Louis Althusser's conception of the "people"/"masses" has long been disparaged or merely forgotten. Instead of taking Althusser's "people"/"masses" as a cliché out of his "bankrupt" anti-humanism, this paper offers a Maoist, or more precisely, a Maoist-Machiavellian perspective to revisit Althusser's "people"/"masses." Given the overlapping of the heyday of Althusser's Maoism (starting in the mid-1960s), the Chinese Cultural Revolution, and the ever-increasing presence of Machiavelli in Althusser's thinking (from the early 1960s), it is imperative to trace their connections and trajectories.

The interrogation of Althusser's Maoism-Machiavellianism may shed light on how Maoism and Maoist ideas of the "people"/"masses" serve as a "China Question of Western Theory" (Liu, "China Question" 17-8). In Liu Kang's view, "China" is conceived as a singular question, or a problematic, for Western theory as the Other, exterior to its conceptual framework. Meanwhile, the China question as such is ineluctably internalized in Western theory, as an immanent part of the western universalist thinking of subjectivity, social formations and (post-)modernity. Moreover, Liu posits that the China question is not only practical and empirical, but theoretical, too, in that "China" is at the theoretical core of Althusserian high theory, in the guise of Maoism, which, in its multiple incarnations, is itself an invention of western theoretical edifice. Meantime, Maoism inspired various kinds of Third World, anticolonial insurgencies, which in turn can be traced to the western connections, in cases such as the Khmer Rouge's chieftain Pol Pot, whose Parisian education in the 1960s exposed him to Maoism.

In what follows, I try to juxtapose Althusser's Maoism with his Machiavellianism along with his other resources such as Leninism and Gramscism. I argue that the very conception of the "people"/"masses" in Althusser's Maoism meshes well with his Machiavellianism, and his MaoismMachiavellianism enables him to reconfigure a notion of "people"/"masses" that is non-humanist, nondeterministic and non-historicist. Such a notion serves as a central conceptual rubric by which to rethink Althusser's ideas of a communist party, historical agency, class struggle and theory of the encounter. Furthermore, such a notion favors reflections on Post-Althusserian radical theories and viable political subjectivities in our time. If, as Sotiris suggests, the absence of an "Althusserian politics" doesn't necessarily mean that "there is no use to be made of Althusser's work in any attempt to rethink radical and even revolutionary politics today" (525), I would like to go further and ask: What does Althusser's Maoism along with his Machiavellianism have to offer for rethinking postAlthusserian radical theory and politics today? And why is Maoism persistently present in inquires on the political subject(ivity), social formations and (post-)modernity in Althusserianism and postAlthusserian radical theories?

\section{Maoism-Machiavellianism and the "People"}

Whereas Maoist influences on the conception of "people"/"masses" became most legible from the mid1960s, Althusser's earlier use of the term can be traced back to Montesquieu: Politics and History (1958), in which he identified "the 'puissance' of the masses of the people" as the "fourth 'puissance'" in terms of traditional division of power (103-4). It then appears in Rousseau: The Social Contract (1965), in which Althusser insisted on the "décalages (discrepancy)" in Rousseau's text, that is, the people or Recipient Party Number Two cannot be "pre-existent" to the contract and thus the social contract is actually "an act of constitution of the Second RP for a possible contract" (Althusser, Politics and History 130-1). In other words, Althusser's (as well as Gramsci's) political question is no longer about how to "govern a people," but "how to produce it"(devenir-peuple) (Del Lucchese 16).

Since Rousseau failed to conceive of the "production" or the "constitution" of the people, then who succeeded, in Althusser's view? Althusser's view, success involves thinking within the non-humanist and non-teleological Althusserian scheme of "subjectivity" and theory of encounter. The candidates would then be Gramsci, Lenin, Machiavelli, and ultimately Mao. To understand such a lineage, one needs to juxtapose Althusser's reading of Machiavelli, his reading of Mao and the Cultural Revolution since 1960s. It was at this crucial historical conjuncture that Althusser's Maoist formulations were at their apex, and, exactly at the same time, Machiavelli was very much in his mind. Furthermore, 
Althusser's so-called "theoretical turn" occurred soon after the publication of For Marx (1965) and Reading Capital (1965). What is the Maoist-Machavellist connection then? As Goshgarian revealed, at least since Althusser's notes of summer 1966, he was thinking about the "theory of the encounter or conjunction" (Encountering 107), and his theory of encounter can even be dated back to "Contradiction and Overdetermination" (1962) ("Introduction" xxxv; xxxix). I argue that it is Althusser's Maoism and Machiavellianism that hold the clue for an Althusserian version of the conjunctural, aleatory "subjectivity" as a rebuttal of the structuralist, functionalist accusation against him, especially after the May 68 event.

To reveal the linage of Althusser's "people"/"masses" and how Mao and Machiavelli got involved, I attempt a cross-reading of such a genealogy:

1) Althusser mentioned reading Mao's Selected Reading from the Works of Mao Tse-tung starting in the early 1950s (Althusser Spectre 247) and after Mao published On the Correct Handling of Contradictions Among the People (hereafter as "Handling") in 1957, Althusser quoted it in his books, letters and notes.

2) Althusser published Montesquieu: Politics and History in 1958, and started reading Machiavelli in the early 1960s. Then his Rousseau: The Social Contract came out in 1965.

3) Althusser anonymously published "On the Cultural Revolution" in 1966 which included the concept "mass ideological revolution."

4) Letters from inside the Italian Communist Party to Louis Althusser and his interview "Philosophy as a Revolutionary Weapon" were published in 1968 and involved Mao's Handling, mass line, masses make history.

5) Althusser published Machiavelli and Us in 1971 expressing his dissatisfaction with the problematic "duality" between the people and the Prince (Althusser Machiavelli and Us 26). 6) Althusser published "Elements of Self-Criticism" and "Reply to John Lewis" in 1972 involving Mao's class struggle, mass line and masses make history.

7) Althusser published Machiavelli's Solitude in 1977 in which he again mentioned the mass line.

Although Althusser's preoccupation with Mao roughly corresponded to the Mao era of the PRC (1949-76), even in the post-Mao era, his Maoist obsession still lingered, as his autobiography L'avenir dure longtemps revealed. Therefore, one should never lose sight of this historical context when looking at Althusser's theoretical work and his China connection, since, in almost every moment, Althusser's thinking and writing were the results of both the immediate political circumstances and his obsession or metamorphosized imagination of China. And Althusser's Machiavellianism was interwoven with the "China in our head" (Robcis 52) and the "Maoism in our head."

\section{"What does 'the People' mean?"}

To answer how to produce the "people" conceptually and then in the real world, the first and foremost step is to figure out what the "people" means. In his letter to Macciocchi on March, $11^{\text {th }} 1968$, Althussser quoted and imitated Mao's method of pinpointing the people in his Handling so as to figure out "what is really going on among 'the people" and to asked the "absolutely essential question for every political undertaking: what does 'the People' mean, today, in Italy?... what classes make up 'the people'? What fractions of classes are involved beyond the proletariat and poor peasants? How, today, are the poor peasants defined?..." (Althusser \& Macciocchi 4-5) Althusser strictly applied Mao's method to urge a concrete reexamination and redefinition of every class, every fraction of the constitution of the people, and believed political actions are possible only by answering the question of "What, today, comprises the people in a given country (today, because the composition of the people varies historically; in a given country, because the composition of the people changes from place to place)" (5). Althusser's emphasis on "today" and "in Italy," in other words, on the singularity of a certain constitution of the "people," clearly echoed Mao's view that "The concept of 'the people' varies in content in different countries and in different periods of history in a given country" (Mao, Handling 100).

Mao's definition of the "people" is indeed a "combination of a subtle formalism and a grounded or situated politics" (Clint 94). Mao did emphasize the always conditioned, concretized analysis, and excluded any predetermined, preconceived notion of "what is really going on among 'the people."' It is worth mentioning that Althusser bizarrely identified Mao's definition of "the people" as "one hundred percent Leninist" (Althusser \& Macciocchi 4), since the above definition and the centralization of the problematic of the "people" in politics per se is indeed invented by Mao in the tradition of Marxism, and Lenin obviously did not belong to the theorists of the "people"; instead, he believed that the masses for masses had to be "organized and disciplined" by "a revolutionary elite" (Maurice 18-9). A possible explanation would be that the "Lenin" here is an aleatory Lenin, namely, a "Machiavelli-Lenin" 
or "Lenin-Machiavelli." In other words, instead of being a slip of tongue, the "one hundred percent Leninist" phrase here invites us to read Mao's definition of the "people" from a conjunctural, aleatory perspective. It needs to be added that the problem of the "production" or the "constitution" of the people would not be effectively tackled by Mao and Machiavelli without Althusser's reading of Gramsci. One of the aspects that Althusser undertook from Gramsci is his "readiness to regard Vladimir Lenin as a Machiavellian" who tends to be interested in "the specifics of the singular situation" (Breckman 244).

According to Althusser's appropriation of Mao's definition of the "people" to discuss Italy's concrete conditions, it could be argued that the equation of Mao's definition as "one hundred percent Leninist" really meant Mao's definition is one hundred percent conjunctural, aleatory, or Machiavellian. Mao's "people" should be read as a dependent variable on the concrete, singular, temporal and spatial conditions and thus resisting any pre-given, determinist presupposition. Therefore pinpointing the fluidity and constitution of such a variable is precisely the premise of any political action. Such a conjunctural reading of "people"/"masses" keeps occurring in Althusser's writings. In his letter to Macciocchi on November 30, 1968, Althusser reiterated the "concrete analysis of the concrete situation...and 'the masses'..." (Althusser \& Macciocchi Letter 300). The phrase "concrete analysis of the concrete situation" in Althusser's writings should be taken as a coded message embedded at once in Leninist and Machiavellian discourses, or as Balibar puts it, "Althusserians of the Conjuncture" with Althusser's "Leninist" and "the Machiavellian" analysis, or, "in the name of 'the concrete analysis of concrete situation" (166). Therefore, the above "concrete analysis" of "the masses" reaffirmed the volatility and indeterminacy of the "people." Even in "Something New" (1974), echoing his 1968 letters, Althusser still persistently required a "detailed concrete analysis" of the "definition of the French people" (Althusser, Self-Criticism 212), since the uncertainty and singularity of the "people" necessitates the ceaseless process of definition and re-definition. In this sense, Althusser's conjunctural reading of the "people" based on Mao's definition is arguably not entirely alien from Ernesto Laclau's "people" as one of empty signifiers which always enable the particulars to "take up the representation" of the universals (Laclau, "Democracy" 11). Although Laclau rejected any forms of universalism for the sake of radical democracy, and for Laclau and other post-Althusserianists, Althusser was irredeemably stuck in a Leninist, partisan politics, the primacy of the particularity and singularity over universals in terms of the "people" might be the preposition that Laclau unwittingly shared with the "Althusserians of the Conjuncture."

\section{The Maoist "People" and the New Principality}

It would be necessary to further link the Maoist, conjunctural "people" to Althusser's main concern, his theory of encounter, that is, the "vide" or "void", since the non-existence of the "people" as a readymade, stable, essentialist entity is inherently an integral part of the "void," which Althusser believed is "empty in order to be filled" by "the action of the individual or group who will come and take a stand there, so as to rally, to constitute the force capable of accomplishing the political task assigned by history" (quoted from Breckman 245). In other words, taking the Maoist non-preconceived "people" as the premise, who would fill the "void"? And what political actions should be taken in order to produce the people? The answer is highly relevant to Maoism and Machiavellianism: "A new Prince in a new Principality," or a "New Party" which relies on "the masses" and applies "a mass line in mass actions," on the basis of radical repulsion of the Stalinist principle of "the cadres decide everything" (Althusser, Self-Criticism $171 ; 214-5)$. While politically, it seems to be quite self-explanatory why Althusser turned to Mao's mass line considering his anti-Stalinist political aspiration, theoretically, it is arguable that it was due to Althusser's dissatisfaction with Machiavelli's "décalages" that Maoism came into play.

One fact worth noticing is that "the first version of Machiavelli and Us was written at the very same time as the important work "Elements of Self-Criticism" in 1972 (Lahtinen 116), and also in the same year, Althusser published "Reply to John Lewis." Considering "Elements of Self-Criticism" and especially "Reply to John Lewis" have long been known as some of the most Maoist texts, it again would be necessary to read between Althusser's Maoism and Machiavellianism with Gramsci as the necessary mediation. Althusser followed Gramsci's Marxisation and transcoding of Machiavelli's Prince into modern communist parties, which allows the Maoist communist party to be introduced as an earthly, flesh-and-blood embodiment of the modern Prince. What is more, following Gramsci as well, Althusser insisted on a popular perspective to read Machiavelli, since in the class struggle against the nobles, "the Prince must rely on the people," that is to say, "Prince's absolute power is 'popular" (Althusser Machiavelli and Us 62; 103). That is why Althusser persistently sought Prince-becomingpeople and people-becoming-Prince reciprocal dynamics which Gramsci had predicted in his reading of Machiavelli: "Machiavelli merges with the people, becomes the people" (Gramsci 126). However, in 
Althusser's symptomatic reading of Machiavelli, there was an irreducible "duality" between the people and the Prince: while the Prince "must become a popular Prince, he is not himself the people," and "equally, the people are not summoned to become the Prince" (Althusser, Machiavelli and Us 26). It is precisely at such a moment that the Maoist mass line and mass party intervened as a possible solution.

Chinese revolution and Mao's ideas of the mass party and mass line had consistently been one of Althusser's main resources to conceive of the "New Prince" and with "new" Principality. There is a clear continuation from what Macciocchi mentioned in her letter to Althusser on May 3, 1968 about "what Togliatti had defined as a mass party, or a party of a new type" (Althusser \& Macciocchi 129) to what Althusser discussed later about the conception of a "New Party" which relies on "the masses" (Althusser, Self-Criticism 214-5), considering Althusser and Macciocchi's shared interest in Maoism and Chinese revolution. Althusser declared that a Communist Party "must have a 'mass' revolutionary political line," namely, "a completely original and unprecedented kind of relationship with 'the masses." While, as Gramsci revealed, Machiavelli had "a kind of presentiment" of such a relationship, "what we need today is something which goes far beyond a simple presentiment of the problem., Althusser then continued, "The Russian and Chinese Revolution allow us to be more specific" (Althusser \& Macciocchi 300). Clearly, Althusser saw in the Chinese Revolution a realization of Machiavelli's "presentiment." But then, how did it happen? Soon after quoting Mao's Handling and its definition of the "people," Althusser claimed, "only by knowing what 'the people' means can you then develop: (1) a mass political line; (2) corresponding political actions" (Althusser \& Macciocchi 5). As mentioned above, for Althusser, the Maoist "people" exists as conjunctural, aleatory uncertainty in every singular conjuncture, in Althusser's words, the masses are a "part of the concrete situation" (Althusser \& Macciocchi 300). Or, in Machiavelli's words, a part of the "fortuna," waiting to be summoned by the Prince with the "virtù" and transformed into "political duration" (Althusser Machiavelli and Us 75). Just as the "people" cannot be predetermined and preconceived, the Prince is also "a pure aleatory possibility" (26). Considering the "individual who is to encounter fortuna" is "unknown" and has "no name" (76), the namelessness of both the Prince and the people before the encounter of the virtù and the fortuna, or before the "void" being filled, suggests that the naming, "becoming" or the formation of the Prince and the people belong to the same reciprocal process, which leads to the necessity of "popular base."

"The new Prince must be "creating a political base" which is "completely new, and sweep away the old political forms," such a political base, as Althusser added, is exactly the "popular base" (Althusser Machiavelli and Us 102), with the phrase "popular base" here being arguably akin to Maoist "mass base." Moreover, this popular base must be "created" specifically for the "new" Prince from the void, because, as Gramsci puts it, not the "generic" people, but only the people with whom the Prince "feels identified" from a Machiavellian perspective (Gramsci 216). For Althusser, this is the "popular base." That is why Althusser demanded "a mass political line, strong enough and flexible enough to prepare the Party, even when the revolution is still far off" (Althusser, Self-Criticism 214). The flexible mass line helps "prepare the party" on the basis of the uncertainty of the "people" and the void of any mature, favorable conditions for the revolution. Meanwhile, it prepares the people to be a new people. That is why Althusser emphasized that the party should pay "the most careful attention" and analyze "what the masses... have in their minds" and then offer and explain the political line to the masses until the "masses are able to recognize their own will" (Althusser \& Macciocchi 300).

It is through such an infinite, circulated practice of the flexible mass line that the New Prince/party can be configured in an Althusserian fashion as "the first ideological state apparatus" (quoted from Lahtinen 13-4). This "first" ISA can then capture the "fortuna" of the precariousness of masses' minds and subsequently create a new people, with which the Prince/party can be identified. In other words, it is Mao's mass line that helped in amending the irreducible Prince-people "duality" under Machiavelli's rubric, and eventually constituting an "original" and "unprecedented" dynamic of Princebecoming-people, or, vice versa, of people-becoming-Prince, to fill the void. It is well-known that post-Althusserian radical theories and their versions of Maoism unfolded in a politics-without-Prince formulation, with an outright dismissal of Althusser's Leninism and anti-humanism. Even so, Althusser's above conjunctural reading of the Maoist mass line and mass party arguably is in sync with Badiou's idea of the party of the "event," namely, the "real characteristic of the party is not its firmness, but rather its porosity to the event" (Badiou, Metapolitics 74). Althusser and Badiou, in brief, all believed that the party should be the locus of fluidity and newness.

\section{Maoist "People" and the Two Theses of "Reply to John Lewis"}


While Rancière ridiculed Althusser's appeal to the "people" as a weird act of "dressing up in 'popular' garb" (Rancière, Althusser's Lesson, xx), a response to the May 68 event that was long overdue, Althusser's compliment of the "people"/"masses" in "Reply to John Lewis" that Rancière mocked was actually the outcome of his long-term rumination on anti-humanism and theory of encounter, as well as on Maoism and Machiavellianism.

"Reply to John Lewis" is well-known as one of Althusser's most Maoist texts, which Althusser selected from all his writings to send to Mao directly after his aborted trip to China in 1974 (Althusser, Longtemps 564). In this letter, Althusser elaborated two main theses of historical dialectics: Thesis One: "it is the masses which make history"; Thesis Two: "the class struggle is the motor of history." More importantly, of these two theses, Thesis One "must be subordinated to Thesis Two" (Althusser, Self-Criticism 50). Significantly, these two theses and especially their hierarchic order are the outcome of Althusser's reading of Maoist "people" and his imagination of China. One finds his Machiavellianism lurking somewhat underneath them, too.

Why is it that the thesis of "the class struggle being the motor of history," a "nominal Marxist" and "certainly Maoist" notion, served as the "basic Althusserian proposition after 1965" (Elliot 150)? Politically, Althusser insisted on class struggle in order to chart a new revolutionary route from the previous bourgeois humanist pathway, marred by determinism, historicism and teleology. In Althusser's view, humanism and historicism are both Hegelian variations, which only replicated the "economistic and mechanistic interpretation" of the Second International (Althusser, Capital 138). It is in this sense that Althusser believed the Chinese Communist Party served as the antithesis to both the French Communist Party, which promoted humanism and aimed to unite "contractual partners" to build "an advanced democracy," and the Soviet Communist Party, which claimed that "everything is for man" (Anderson 39). However, Althusser's siding with Mao/Maoist China/Maoist "people" derived from deeper theoretical considerations rather than merely from political expediency.

Although Thesis One and Two are both conceived of as Marxist-Leninist theses (Althusser SelfCriticism 59), Althusser especially stressed the categorical primacy of Thesis Two over Thesis One. I would like to connect such primacy with the thesis Althusser continued to argue in his later writings, that class struggle "has primacy over the contending classes" (Goshgarian "Translator" xlv). That is to say, the absolute supremacy of class struggle supersedes the "contending classes," namely, the masses and non-masses. As Vatter contends, the primacy of class struggle over class signifies Althusser's quest for a class struggle which is independent from the Marxist, teleological social antagonism, and the "necessity of overcoming the antagonism in a synthesis" (Vatter). It is exactly in this sense of searching for a non-synthesis that I think Althusser's "class struggle" is not Marxist, but Maoist.

The original title of "Reply to John Lewis" for New Left Books was "Mao's Never Forgot the Class Struggle!" (Elliot 229), citing in a salutary gesture Mao's slogan "Never Forgot the Class Struggle!" delivered in Mao's 1962 speech at the $10^{\text {th }}$ Plenum of the Central Committee of the CCP's $8^{\text {th }}$ Congress. This speech expanded class struggle to the whole period of socialism prior to the onset of communism, and resulted in the catastrophic Cultural Revolution (1966-76). In fact, as Liu Kang observed, the Handling which was given out in 1957 already formulated the necessity of class struggle and foreshadowed the Cultural Revolution (Liu, "Problematic" 19). Mao's implacable assertion on the "one divides into two" reached its peak in his criticism against Yang Xianzhen's synthetic thesis of "Two United into One." In this respect, Mao provided Althusser with a theoretical justification for protracted class struggle that negates any forms of synthesis, a negation Althusser had long awaited in order to consolidate his historical dialectics. Furthermore, class and class struggle runs through Mao's conception of "people"/"masses," and this is precisely why Althusser felt free to embrace his conception without worry of compromising class struggle. Althusser would never go for the class alliances excluding the doctrine of Marxist class struggle as Popular-Front, French Communist Party's "advanced democracy" and many other social-democratic theories attempted. On the contrary, Mao invented a concept of "people" that is about revolutionary unity, which is always based on class and yet broader than class (Hu 6). In fact, the very premise of Mao's "people" as "the broadest section," constituting "more than 90 percent of the total population" is Mao's insistence on people's democratic dictatorship, a variation on the dictatorship of the proletariat, which still positioned the working class as the "class that leads the revolution" (Mao, Yan'an 463-5). Therefore, Althusser's endorsement of such a class struggle-based "people" helped him strike back against the accusations of being a structuralist and functionalist that he had long suffered. In addition, juxtaposing Mao and Althusser on matters of the "people," "class struggle" and the "party" in texts such as Machiavelli and Us and "Reply to John Lewis," or engaging a Maoist symptomatic reading of these texts, conceptual similarities between Mao and Althusser come to the fore: Althusser insisted that Machiavelli needed 
"to be a man of the people" (Althusser, Machiavelli 25), and Mao talked about the necessity of integrating with "the workers and peasants" (Mao, Contradiction 132). Althusser believed that Machiavelli's object is the "common people" or the "vast majority," Mao aimed at "more than 90 percent of the total population." Althusser claimed that Machiavelli's invocation of the people is to promote class struggle (Althusser, Machiavelli 25), Mao stressed that the fight for victory over imperialism is "the logic of the people" (Mao Selected Works IV 428). Althusser's "popular" reading of Machiavelli with its emphasis on antagonism is arguably quite Maoist.

Another implication of the primacy of Thesis Two over Thesis One points to the prioritization of theory of the encounter. As Goshgarian incisively observes, Althusser's "encounter" could be identical to "class struggle" (Goshgarian, Encountering 89). I would like to add that the categorical primacy of Thesis Two refers to none other than the categorical primacy of the encounter, the contingency and the aleatory. And for Althusser, it is from his Maoism that a non-humanist, non-determinist, nonevolutionist notion of "people" emerged, which belongs to an aleatory socialist and communist revolution. Humanism tends to revisit "a story of the journey of Man towards Communism" (Simon 22), hence the progressive slogan of Khrushchev's "peaceful transition from capitalism to socialism." On the contrary, Mao always questioned any unspecified and abstract narratives of humanity and human nature. Mao's "people," with its emphasis on divisions and dialectics of division and unity, accommodates contradictions, divisions, and class struggle. Insofar as class struggle is protracted, contradictions and divisions among and outside the people will continue. Mao also applied his "one divides into two" philosophy to the "people," and believed that the people was produced and reproduced precisely through the process of division and struggle, hence his formula of "unity, criticism, unity" (Mao, Handling 109). Mao's emphasis on the contradictions among the people should also be seen as a logical extension of his insistence on the primary of internal contradictions over external contradictions in On Contradiction: "Contradictoriness within a thing is the fundamental cause of its development" (Mao, Vol I 313). Mao's general belief in perpetual contradictoriness and especially internal contradictoriness logically led him to view contradictions immanent in the constitution of the people as such. Therefore, by subjugating the conception of the "people" per se to the dialectics in the post-revolutionary era after the formation of the people and after the completion of mass-scale socialist transformation, Mao immensely complicated the problem of building socialism as an indeterminate and precarious process. In Mao's mind, the 1956 Hungarian Uprising, triggered by the Soviet suppression of the reformist experiments of the Hungary Communist Party, was a living embodiment of non-antagonistic contradictions being metamorphosized into antagonistic ones (Mao, Handling 110). Therefore, non-antagonistic contradictions or contradictions among the people did not exclude antagonistic contradictions or class struggle. Instead, the former existed on condition that the latter was on the horizon. Not only that, Mao further complicated socialist transformations by warning "the class struggle in the ideological field" would be "long and tortuous" and even "acute" (140). Althusser clearly echoed Mao by suggesting the forwardness and backwardness of ideology could affect politics, economics and eventually social formations (Yan 8). The "long," "tortuous" ideological contradictions and class struggles among the people/between the people and the non-people, as well as the "mass ideological revolution" (Anonymous 2), thus had a stake in the forwardness and backwardness of social formations. Consequently, Mao's "people" contained a non-linear socialist/communist logic, and was precisely consistent with the Marxist historical dialectics that Althusser conceived, which "allows for lags [décalages], distortions, regressions without repetition, leaps, etc." (11). Such a historical dialectics, with its contingent logic about history, is already an aleatory vision of social formations, or, theory of the encounter.

The Maoist notion of non-synthetic divisions ought to be viewed as a "China Question," in Liu Kang's parlance, in western Marxist theory, particularly that of Althusser, Rancière, Badiou, Laclau, and so on. Maoist division helped all of these theorists confirm that divisions, instead of being purely negative and deconstructive, are actually positive, constructive and even necessary for the production of any political subjectivity. Althusser wrote in his notes that Mao's "one divides into two" or "division in the revolutionary sense" is "a good and not a bad thing" since "it helps to elevate man's ideological conscience, it reinforces the unity of revolutionaries, it favors the development of the proletariat's revolutionary cause and it makes society progress" (quoted from Robcis 60). Post-Althusserians, in spite of their rebellious stance against Althusser, inherited Althusser's purely imaginative, pedantic views about China, and conveniently expanded and grafted Mao's division with various versions of post-Marxist political subjects of the difference. Maoist logic of division among the people clearly runs through Rancière's insistence on the internal divisions of the people as "the primary condition of the exercise of politics" (Rancière, Disagreement 87), Laclau's populist reading of "people" as "a historical actor out of a plurality of antagonistic situations" (Laclau Populist 122), and Badiou's division between 
working class and proletariat (Badiou, Contradiction 9-10). In other words, they found in Maoist division a weapon to liquidate any political subjectivity that endorses any non-divided, homogeneous One or oneness, and formulated Maoist division to serve their respective anarchist, populist or neocommunist agendas.

Compared to Thesis Two, Thesis One, "it is the masses which make history," is where Althusser's Maoism significantly exceeds his Machiavellianism. Rancière regards it as "a political thesis of Maoism" instead of a "philosophical thesis of Marxism-Leninism" (Rancière Lesson 14). If one again juxtaposes Machiavelli and Us with "Reply to John Lewis," then Althusser's dissatisfaction with Machiavelli, that is "the people is not yet 'the subject' of history" (Althusser, Machiavelli and Us 26-7), was perfectly offset by Thesis One. Thesis One was never meant as a "'popular' garb" (Rancière) that Althusser put on as a stopgap measure; instead, it is the climax of his long search for a possible theoretical position of the "people"/"masses," from the Recipient Part 2 (Roussearu), to the "fourth 'puissance'" (Montesquieu) and to Machiavelli's "people". Since Althusser refuted the existence of "a Subject" of history, and only acknowledged class struggle as the "motor" of history (99), for him, China with its "hundreds of millions" of people who cannot be "identifiable by the unity of its 'personality, '" turned out to be the epitome of the non-existence of the "Subject" (Althusser, Self-Criticism 48). Therefore, in Althusser's understanding, Chinese non-individualist, non-humanist, non-teleological "masses" thus comes closest to the "subject" of history that Althusser could ever acknowledge: such "masses" making history could hold the place of "'the subject' of history," namely, "subjectivity without a subject" (Badiou, Metapolitics 66), without degenerating into the Subject of history in a Hegelian fashion.

Paradoxically, Thesis One is also the site where the clashes between Althusser's Maoism and Mao's views, and between Althusser and post-Althusserians arise. For Althusser, the very premise of Thesis One is its absolute subordination to Thesis Two. However, When Mao stressed that "the class struggles of the peasants, the peasant uprisings and peasant wars constituted the real motivating force of historical development in Chinese feudal society" (Mao, Selected II 308), he obviously did not frame them in an either-or or hierarchic relationship. Instead, the two theses are unconditionally blended. Mao never hesitated to intersect the motor and the Subject of history to one point, namely, the people/masses. On the contrary, Althusser purposely differentiated and left the two theses in unsolved tension. Although Thesis One is brought up as the forceful assailment against John Lewis's humanist thesis "it is man who makes history" (Althusser, Self-Criticism 59), it is the differentiation and hierarchy between the two theses that rules out any forms of humanism for good. For Althusser, Thesis Two guarantees Thesis One will not end up on the old path of humanism, taking masses as the philosophical/political origin and telos. Therefore, the primacy of Thesis Two over Thesis One, following the above discussion, points to the primacy of the theory of encounter over any forms of teleological, determinist humanism.

Then why did Althusser turn to Mao's "masses" in the first place considering their obvious unbridgeable divarication on the "subject"/Subject of history? Liu Kang has persuasively demonstrated that Mao is simultaneously a subjectivist, or voluntarist, and an objectivist, a determinist, and an antideterminist----Mao in this respect is the contradiction and self-contradiction par excellence, and Mao as such was ignored by Althusser, due to his own objectivist, limited views (Liu, "Legacy" 234-255). Such a multi-faceted ambiguity sows the very seeds for Maoism's versatility favorable for both Althusserianism and post-Althusserianism. While Althusser read an anti-humanist Maoism from Mao's objectivism, Rancière and Laclau exacted a voluntarist one from Mao's subjectivism. Rancière restored Mao's original "humanist" wording which emphasized the people as the "creator" of history (Rancière, Lesson 14; 161) and implicitly criticized the way in which Althusser always stuck to masses "making" history. Laclau's populist passion and radical democratic project were also inspired by the "popular surface" constituted among Chinese people (Laclau, Popular 122). However, in view of the current global upheavals featuring rampant nationalism, populism, anarchism, and other kinds of radicalisms, what are the practical implications of Althusser's class-struggle-based, non-humanist "people"/"masses"? Is it really a worn-out antique, or just an untimely prognostic?

\section{Coda}

Althusser's "people"/"masses", out of his Maoism-Machiavellianism, might still be able to speak to our time. Even if there is not an "Althusserian politics" (Sotiris), is it still possible that there is a politics of being "almost" in Althusser's "people"/"masses"? That is, Althusser's non-determinist, nonteleological, non-humanist "people"/"masses" is "almost" a people of the difference or a people of the event, just like his aleatory socialist/communist vision is "almost" a politics of the event. The complex genealogy of Althusserian Maoism and Mao's Thought in China, though by no means vindicating the 
viability of Western Maoism and Third-world Maoism, does point to the enduring presence of radical theories and practice in today's world, which is not an "almost" but a reality.

\section{Acknowledgement}

I would like to thank Professor Liu Kang for his insightful and detailed advice on this paper. I would also like to thank Professor Wu Zifeng for supporting the idea of doing a Maoism-Machiavellianism study, and sharing with me an anecdote that he heard from Étienne Balibar: in the early days, Althusser always hid Mao's works in the drawer of his desk, while in later days, he instead hid Machiavelli's. Such an anecdote helps testify to the "Maoism-Machiavellianism" argument in this article.

\section{Works Cited}

Althusser, Louis. Essays in Self-Criticism. Translated by Grahame Lock, NLB, 1976.

Althusser, Louis. Interview with Maria Antonietta Macciocchi. "Philosophy as a Revolutionary Weapon." Translated by Andy Blunden. https://www.marxists.org/reference/archive/ althusser/1968/philosophy-as-weapon.htm Althusser, Louis. Machiavelli and Us. Translated by Gregory Elliot, edited by François Matheron, Verso, 1999. Althusser, Louis, Olivier Corpet, and Yann Moulier Boutang. L'avenir Dure Longtemps. Stock, 1992.

Althusser, Louis. Politics and History: Montesquieu, Rousseau, Hegel and Marx. Translated by Ben Brewster, NLB, 1972.

Althusser, Louis and Étienne Balibar. Reading Capital. Translated by Ben Brewster, NLB, 1970.

Althusser, Louis. The Spectre of Hegel: Early Writings. Translated by G.M. Goshgarian, Verso, 1997.

Althusser, Louis \& Maria Antonietta Macciocchi. Letters from inside the Italian Communist Party to Louis Althusser. Translated by Stephen M. Hellman, NLB, 1973.

Anderson, Perry. Considerations on Western Marxism. Verso, 1979.

Anonymous (Attributed to Louis Althusser). "On the Cultural Revolution." Translated by Jason E. Smith, Décalages, vol. 1 no. $1,2010,1-18$.

Badiou, Alain. Metapolitics. Translated by Jason Barker, Verso, 2005.

Badiou, Alain. Theory of the Subject. Translated by Bruno Bosteels. Continuum, 2009.

Badiou, Alain. Theorie de la contradiction. Maspero, 1975.

Balibar, Étienne, Margaret Cohen and Bruce Robbins. "Althusser's Object." Social Text, vol. 39, 1994, pp. $157-188$.

Breckman, Warren. "The Power and the Void: Radical Democracy, Post-Marxism, and the Machiavellian Moment." Political Intellectuals and the Subversion of Progressive Politics, edited byGregory Smulewicz-Zucker and Michael J. Thompson, Palgrave Macmillan, 2015.

Bosteels, Bruno. "Introduction: This People Which Is Not One." What is a People?, edited by Alain Badiou, et al. Columbia UP, 2016, pp. 1-20.

Burnham, Clint. The Jamesonian Unconscious: The Aesthetics of Marxist Theory. Duke UP, 1995.

Choat, Simon. Marx Through Post-Structuralism: Lyotard, Derrida, Foucault, Deleuze. Continuum, 2010.

Del Lucchese, Filippo, Fabio Frosini and Vittorio Morfino ed. The Radical Machiavelli: Politics, Philosophy, and Language. Brill, 2015.

Elliott, Gregory. Althusser: The Detour of Theory. Brill, 2006.

Goshgarian, G.M. "Translator's Introduction." In Louis Althusser, Philosophy of the Encounter: Later Writings, 1978-87. Translated by G.M. Goshgarian. François Matheron and Oliver Corpet ed., Verso, 2006.

Goshgarian, G.M. "The Very Essence of the Object, the Soul of Marxism and Other Singular Things: Spinoza in Althusser 1959-67." Encountering Althusser: Politics and Materialism in Contemporary Radical Thought, edited by Katja Diefenbach, Sara R. Farris, Gal Kirn, Peter D. Thomas, Bloomsbury, 2013.

Goshgarian, G.M. "Introduction." In Louis Althusser, The Humanist Controversy and Other Writings (1966-1967). Translated by G.M. Goshgarian, edited by Francois Matheron, Verso, 2003.

Gramsci, Antonio. Selections from the Prison Notebooks of Antonio Gramsci, edited by Quintin Hoare and Geoffrey Nowell Smith, International Publishers. 1992

Hu, Yamin. "'People' in Chinese Marxist Literary Criticism." Literary Review, vol. 5, 2015, pp. 5-9.

Rancière, Jacques. Althusser's Lesson. Translated by Emiliano Battista, Bloomsbury Publishing, 2011.

Rancière, Jacques. Disagreement: Politics and Philosophy. U of Minnesota $P, 1999$.

Lahtinen, Mikko. "Althusser, Machiavelli and Us: Between Philosophy and Poiltics." Encountering Althusser: Politics and Materialism in Contemporary Radical Thought, edited by Katja Diefenbach, Sara R. Farris, Gal Kirn, Peter D. Thomas, Bloomsbury, 2013.

Lahtinen, Mikko. Politics and Philosophy: Niccolò Machiavelli and Louis Althusser's Aleatory Materialism. Brill, 2009.

Laclau, Ernesto. "Democracy and the Question of Power." Constellations, vol. 8, no. 1, pp. 3-14.

Laclau, Ernesto. On Populist Reason. Verso, 2005.

Liu, Kang. "China Question of Western Theory: A Discussion about Critical Paradigms, Methods and Practices." Journal of Nanjing Normal University (Social Science Edition), vol. 1, 2019, pp. 16-28.

Liu, Kang. "The Legacy of Mao and Althusser: Problematics of Dialectics, Alternative Modernity, and Cultural Revolution." Critical Perspectives on Mao Zedong's Thought, edited by Arif Dirlik, Paul Healy and Nick Knight. Humanities Press, 1997, pp. 234-63. 
Liu, Kang. "The Problematic of Mao and Althusser: Alternative Modernity and Cultural Revolution." Rethinking Marxism, vol. 8, no. 3, 1995, pp. 1-25.

Mao, Tse-tung, On Practice, On Contradiction, On the Correct Handling of Contradictions among the People. National Book Agency Private Ltd., 1967.

Mao, Tse-Tung. Selected Works of Mao Tse-Tung Vol.I. Foreign Languages Press, 1965.

Mao, Tse-Tung. Selected Works of Mao Tse-Tung Vol.II. Foreign Languages Press, 1965.

Mao, Tse-Tung. Selected Works of Mao Tse-Tung: Vol. IV. Foreign Languages Press, 1961

Mao, Zedong. "Talks at Yan'an Forum on Literature and Art." Modern Chinese Literary Thought: Writings on Literature 1893-1945, edited by Kirk A. Denton. Stanford UP, 1996.

Meisner, Maurice. "Leninism and Maoism: Some Populist Perspectives on Marxism-Leninism in China." China Quarterly, vol. 45, 1971, pp. 2-36.

Moufawad-Paul, J. Continuity and Rupture: Philosophy in the Maoist Terrain. Zero Books, 2016.

Robcis, Camille. "'China in Our Heads': Althusser, Maoism and Structuralism." Social Text, vol. 30 no. 1, 2012 , pp. 51-69.

Sotiris, Panagiotis. A Philosophy for Communism: Rethinking Althusser. Brill, 2020.

Vatter, Miguel. "Althusser and Machiavelli: Politics after the Critique of Marx."

Multitudes: Revue Politique, Artistique, Philosophique, vol. 13, 2013. http://www.multitudes.net/Althusser-andMachiavelli-Politics/.

Yan, Fang. "The 'Althusser-Mao' Problematic and the Reconstruction of Historical Materialism: Maoism, China and Althusser on Ideology." CLCWeb: Comparative Literature and Culture, vol. 20, no. 3, 2018.

Author's profile: Fang Yan teaches literature theory at Central China Normal University. Her interests include literary theory and critical theory. Her publications include "Maoism and Western Theory: An Interview with Fredric Jameson" (2017) and "The 'Althusser-Mao' Problematic and the Reconstruction of Historical Materialism: Maoism, China and Althusser on Ideology" (2018). Email: <yanfang112@gmail.com>. This paper is supported by the project "The Recanonization and Contemporization of Marxist Literary Criticism" (19ZDA263). 